\title{
Effect of Supply Chain Information Systems on Firm Performance: An Empirical Case Study
}

\author{
Farideh Haghshenas Kashani \\ Faculty of Management, Central Tehran Branch, \\ Islamic Azad University, \\ Tehran, Iran
}

\author{
Shahram Baharmast \\ Faculty of Management, Central Tehran Branch, \\ Islamic Azad University, \\ Tehran, Iran
}

\begin{abstract}
This study evaluates the effect of supply chain information systems on firm performance in IKAMCO as a empirical case study. For this purpose, The 132 IKAMCO employees selected by simple random sampling responded to a questionnaire. Content validity of the questionnaire has been confirmed by experts in this field; its reliability has been confirmed by using Cronbach's alpha and Fisher's test. Kolmogorov-Smirnov test is used to ensure normality of the data obtained from questionnaire. The hypotheses are tested using SmartPLS software. Results show that the model is well fitted to the data. Findings show that a lean and agile supply chain is effective on supply chain performance and supply chain performance is effective on firm performance. Efficiency of information systems moderates the effect of lean supply chain on supply chain performance and firm performance. However, flexibility of information systems does not moderate the effect of agile supply chain on supply chain performance and firm performance.
\end{abstract}

Keywords-supply chain; information systems; firm performance; PLS; agile supply chain; lean supply chain.

\section{INTRODUCTION}

Information is one of the most important assets of any organization; because of its high and vital value for any organization, information should be well protected [1]. Information is often used for directing processes of employees from top to operational levels. Decision-making is a very important process based on information processing [2]. In recent decades, many scholars have highlighted the role of business information in different aspects of organization as information revolution [3]. In current volatile and competitive environment, the survival and success of organizations depend on the optimal utilization of technologies and information systems which are able to facilitate internal process management and contribute to adaptation to market changes and rapid responsiveness to customer needs by proper flexibility.

Lean supply chain focuses on creation of a value stream in organizational processes through elimination of all wastes in time and inventory and unnecessary costs [4]. Lean supply chain involves inventory management, standard product delivery, waste reduction, quality improvement and management. Agile supply chain refers to ability of a supply chain for rapid response to changes in the market and customer needs [5]. Agile supply chain involves respond to needs, change management, customization and higher production capacity. Efficiency of information systems refers to application of information systems for operational support of intra- and inter-organizational supply chain processes [6]. Efficiency of information systems involves management of materials and parts of suppliers, cost management, quality management for parts and product, production management and parts production line. Flexibility of information systems is evaluated for changes in business practices, competitors, suppliers, customers and generally all people who have influence on the organization and rapid changes in information technology. Flexibility of information systems involves introduction of new products, monitoring of market changes, responsiveness to market changes and change in products. Supply chain refers to a set of methods used for effective and efficient integration of activities of suppliers, manufacturers, warehouses, distribution centers and retailers to minimize system costs and meet requirements by producing and distributing products and services in the right place at the right time. Performance facilitates communication and understanding between employees and supervisors and leads to more favorable working conditions and higher commitment to quality of service. Market share, return on investment, market share growth, return on investment growth, profit margins.

In [7], author evaluated the effect of aligned marketing strategies on supply chain and performance of Entekhab industrial group. They found a positive and significant relationship between aligned marketing strategies and supply chain and supply chain performance. They also found a positive and significant relationship between supply chain performance and performance. In [8], authors evaluated the effect of IT on supply chain capabilities and firm performance in SAIPA. They concluded that IT implementation had a significant effect on supply chain capabilities and performance. This significant effect suggests that IT capability can promote performance and supply chain capabilities. Moreover, IT implementation has direct and indirect positive effect on performance. It is noteworthy that indirect effect of IT implementation on performance is revealed through supply 
chain capabilities. Although supply chain capabilities do not directly increase performance, they increase the positive effect of IT implementation on performance. In [9], the role of information systems of strategic management in strategic decisions of organizations was examined. It was concluded that information systems integrate analytic methods of the organization. These techniques extract concepts from primary information and convert them to decidable forms. In [10], authors analyzed the effect of strategic planning of information systems in improving performance of supply chain management. They concluded that supply chain planning is influenced by strategic planning of information systems. Activities done for development of strategic planning of information systems can be considered as a good guidance for this. By evaluating quality of information and supply chain performance, author in [11] concluded that quality of life is significantly effective on supply chain performance and information sharing facilitates this process. In [6], author evaluated the effect of information systems of supply chain on performance and concluded that information flexibilities have a significant effect on supply chain of companies. Moreover, they showed that supply chain has a significant effect on firm performance. Studying cross-organizational information systems and supply chain performance, authors in [12] concluded that cross-organizational information systems improve quality of environmental factors and significantly influence supply chain performance. In [13], authors examined the relationship between information systems and configuration of activities and success of organizations. They concluded that information systems play a deterministic role in making organizational decisions and they are effective on organizational success. In [14], authors examined the role of information systems on supply chain performance. They concluded that technical, strategic and cultural aspects of information systems improve supply chain performance.

Iran Khodro Mehvarsazan Company (IKAMCO) as the largest producer of axles for gasoline-powered vehicles considers customer satisfaction, profitability, employee welfare, reduced costs, improved quality of products and ontime delivery as a result of proper information systems used in the supply chain. Therefore, the problem of this study is whether the supply chain information system has a significant effect on IKAMCO firm performance.

\section{CONCEPTUAL MODEL}

This study examines the effect of supply chain information systems on the performance of IKAMCO. Figure 1 shows research conceptual model based on the model proposed in [6].

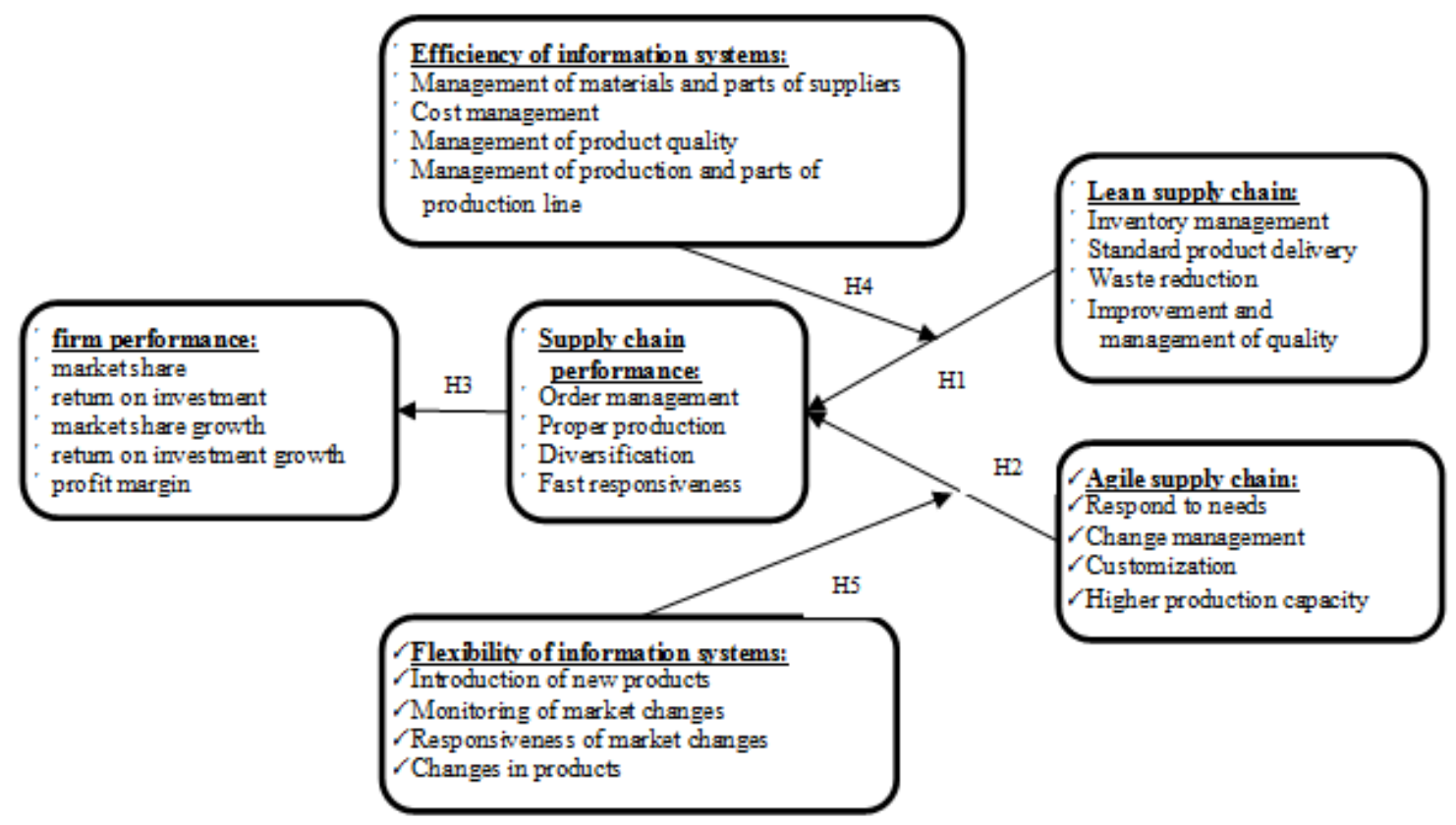

Fig. 1. The research model

\section{A. Research Hypotheses}

- H1: Lean supply chain is effective on supply chain performance.

- H2: Agile supply chain is effective on supply chain performance.

- H3: Supply chain performance is effective on firm performance.
- H4: Efficiency of information systems mediates the effect of lean supply chain on supply chain performance and firm performance.

- H5: Flexibility of information systems mediates the effect of agile supply chain on supply chain performance and firm performance. 


\section{RESEARCH METHODOLOGY}

This was an applied research using descriptive methods for data collection. The studied population included 200 IKAMCO employees who used information systems of supply chain. Cochran formula for finite population was used to select the samples:

$$
n=\frac{(N)\left(Z_{1-\alpha / 2}\right)^{2}(P)(1-P)}{\left.(N-1)(D)^{2}+Z_{1-\alpha / 2}\right)^{2}(P)(1-P)}
$$

where, $\mathrm{n}$ denotes the sample size required; $\mathrm{N}$ denotes the size of statistical population; $p$ denotes the ratio of having the considered characteristic; $\mathrm{z}$ denotes the area under the standard normal curve, which is 1.96 considering $\alpha=0.05$; and denotes maximum error (accuracy).

$$
n=\frac{(200)(1.96)^{2}(0.5)(1-0.5)}{(200-1)(0.05)^{2}+(1.96)^{2}(0.5)(1-0.5)}=132
$$

Thus, sample size was estimated at 132 . To collect data, a questionnaire was designed from [6]. The main structure of questionnaire is shown in Table I.

TABLE I. STRUCTURE OF QUESTIONNAIRE

\begin{tabular}{|c|c|c|}
\hline Variable & $\begin{array}{c}\text { Number of } \\
\text { questions }\end{array}$ & $\begin{array}{c}\text { Question } \\
\text { number }\end{array}$ \\
\hline Lean supply chain & 6 & $1-6$ \\
\hline Agile supply chain & 5 & $7-11$ \\
\hline $\begin{array}{c}\text { Efficiency of information } \\
\text { systems }\end{array}$ & 5 & $12-16$ \\
\hline $\begin{array}{c}\text { Flexibility of information } \\
\text { systems }\end{array}$ & 4 & $17-20$ \\
\hline Supply chain performance & 10 & $21-30$ \\
\hline Firm performance & 6 & $31-36$ \\
\hline
\end{tabular}

\section{A. Validity and Reliability of Questionnaire}

Validity and reliability are essential properties of measurement instruments. Validity determines the extent to which measurement instrument measures the considered trait. Without knowing validity of a measurement instrument, accuracy of data cannot be ensured. In other words, validity determines whether instrument measures the considered concept, or the instrument can measure the trait to be measured. Content validity is usually used to examine constructs of an instrument. Content validity is usually determined by experts in the studied subject. Hence, content validity depends on judgments of experts. Accordingly, the questionnaire used in this study is valid, because it was derived from [6]. Moreover, content validity of this questionnaire was confirmed by the professors and experts in the subject. To ensure reliability of the questionnaire, 60 questionnaires were first distributed among the studied population. Reliability of the questionnaire was examined by Cronbach's alpha and Fisher's exact test, results of which are listed in Table II. Cronbach's alpha $>0.7$ and Fisher's values which are higher than error probability $(\alpha=0.05)$ indicate good reliability of the questionnaire.
TABLE II. RELIABILITY OF THE QUESTIONNAIRE

\begin{tabular}{|c|c|c|c|l|}
\hline Variable & $\begin{array}{c}\text { Number of } \\
\text { questions }\end{array}$ & $\begin{array}{c}\text { Cronbach's } \\
\boldsymbol{\alpha}\end{array}$ & $\begin{array}{c}\text { Fisher } \\
\text { probability }\end{array}$ & Result \\
\hline $\begin{array}{c}\text { Lean supply } \\
\text { chain }\end{array}$ & 6 & 0.914 & 0.472765823 & Reliable \\
\hline $\begin{array}{c}\text { Agile supply } \\
\text { chain }\end{array}$ & 5 & 0.789 & 0.682441032 & Reliable \\
\hline $\begin{array}{c}\text { Efficiency of } \\
\text { information } \\
\text { systems }\end{array}$ & 5 & 0.926 & 0.656109777 & Reliable \\
\hline $\begin{array}{c}\text { Flexibility of } \\
\text { information } \\
\text { systems }\end{array}$ & 4 & 0.792 & 0.161646769 & Reliable \\
\hline $\begin{array}{c}\text { Supply chain } \\
\text { performance }\end{array}$ & 10 & 0.821 & 0.629178337 & Reliable \\
\hline $\begin{array}{c}\text { Firm } \\
\text { performance }\end{array}$ & 6 & 0.858 & 0.392513894 & Reliable \\
\hline Total & 36 & 0.952 & & Reliable \\
\hline
\end{tabular}

IV. RESULTS

\section{A. Demographic Variables}

As findings showed, $92.4 \%$ of subjects were male and $7.6 \%$ were female; $9.1 \%$ were single and $90.9 \%$ were married; $20.5 \%$ aged $25-30$ years, $16.7 \%$ aged $31-35$ years, $16.7 \%$ aged $36-40$ years and $46.2 \%$ were older than 40 years; $5.3 \%$ had high school diploma and lower, $14.4 \%$ had associate's degree, $67.4 \%$ had bachelor's degree and $12.9 \%$ had master's degree; $17.1 \%$ of samples had less than 5 years of experience, $12.1 \%$ had $6-10$ years, $35.6 \%$ had $11-15$ years, $16.7 \%$ had $16-20$ years and $16.7 \%$ had more than 20 years of experience.

\section{B. Hypothesis Testing}

As shown in Table III, sig $<0.05$ rejects the hypothesis on normal distribution of data. Partial least square (PLS) analysis was used to test the hypotheses.

\begin{tabular}{|c|c|c|c|c|c|c|}
\hline $\begin{array}{l}\frac{0}{2} \\
\frac{\pi}{\pi} \\
\frac{\pi}{\pi} \\
\nu\end{array}$ & 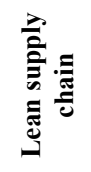 & 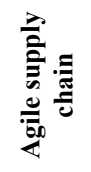 & 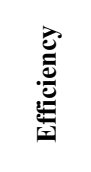 & 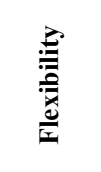 & 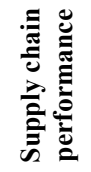 & 兽 \\
\hline $\mathrm{K}-\mathrm{S}$ test & 1.765 & 1.883 & 2.197 & 1.936 & 1.815 & 1.805 \\
\hline Sig. & 0.004 & 0.002 & 0.000 & 0.001 & 0.003 & 0.003 \\
\hline Result & $\begin{array}{c}\text { Non- } \\
\text { normal }\end{array}$ & $\begin{array}{c}\text { Non- } \\
\text { normal }\end{array}$ & $\begin{array}{c}\text { Non- } \\
\text { normal }\end{array}$ & $\begin{array}{c}\text { Non- } \\
\text { normal }\end{array}$ & $\begin{array}{c}\text { Non- } \\
\text { normal }\end{array}$ & Non-normal \\
\hline
\end{tabular}

TABLE III. DISTRIBUTION OF DATA (K-S TEST)

\section{Confirmatory Factor Analysis}

To validate the questionnaire, the confirmatory factor analysis (CFA) is applied for all research variables. The results of CFA are shown in Figures 2 and 3. Table IV shows that the items are well fitted and the questionnaire is able to measure the variables. 


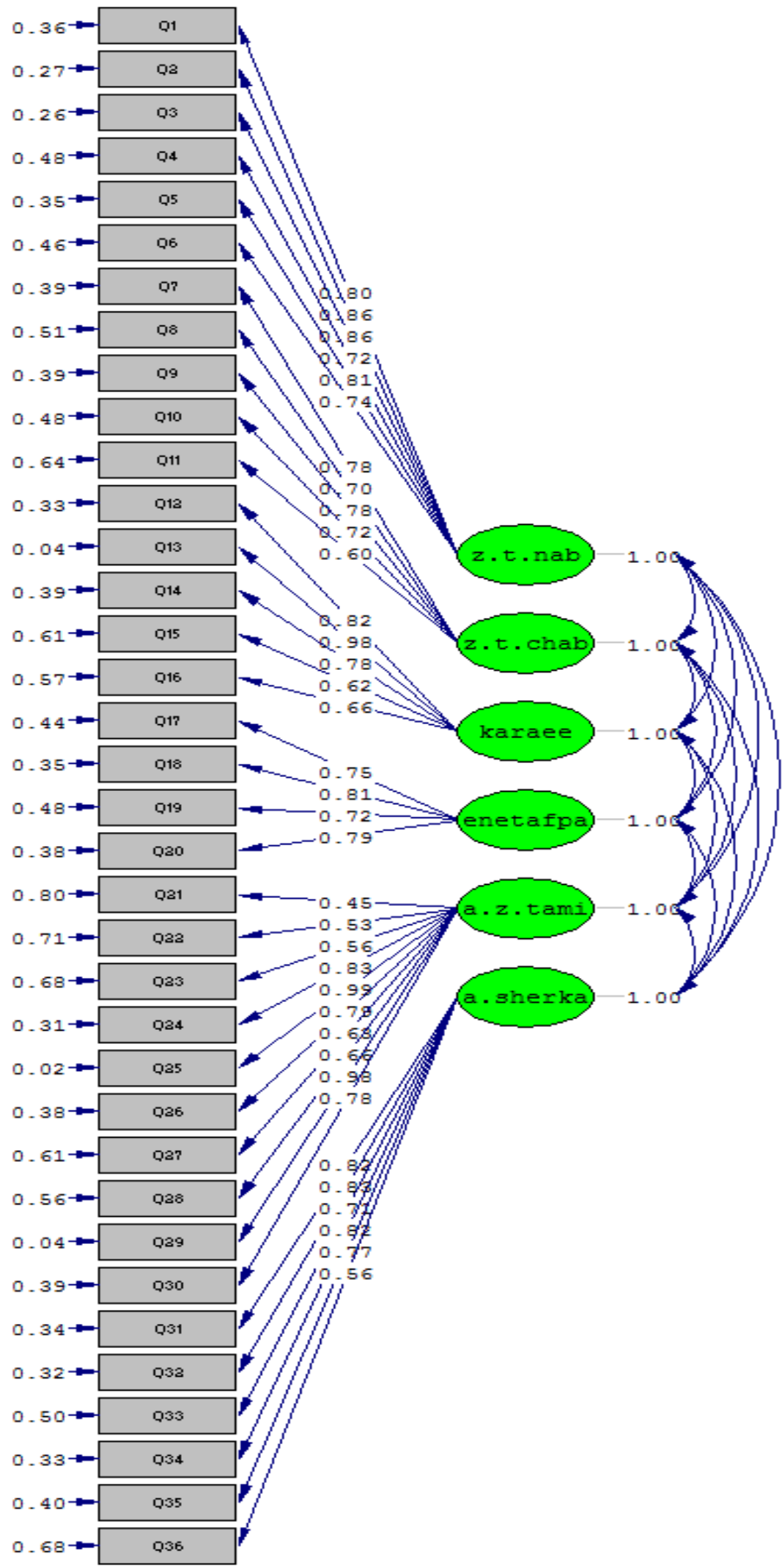

Chi-Square=1324.34, df=579, P-value=0.00000, RMSEA=0.052

Fig. 2. Estimates of significance 


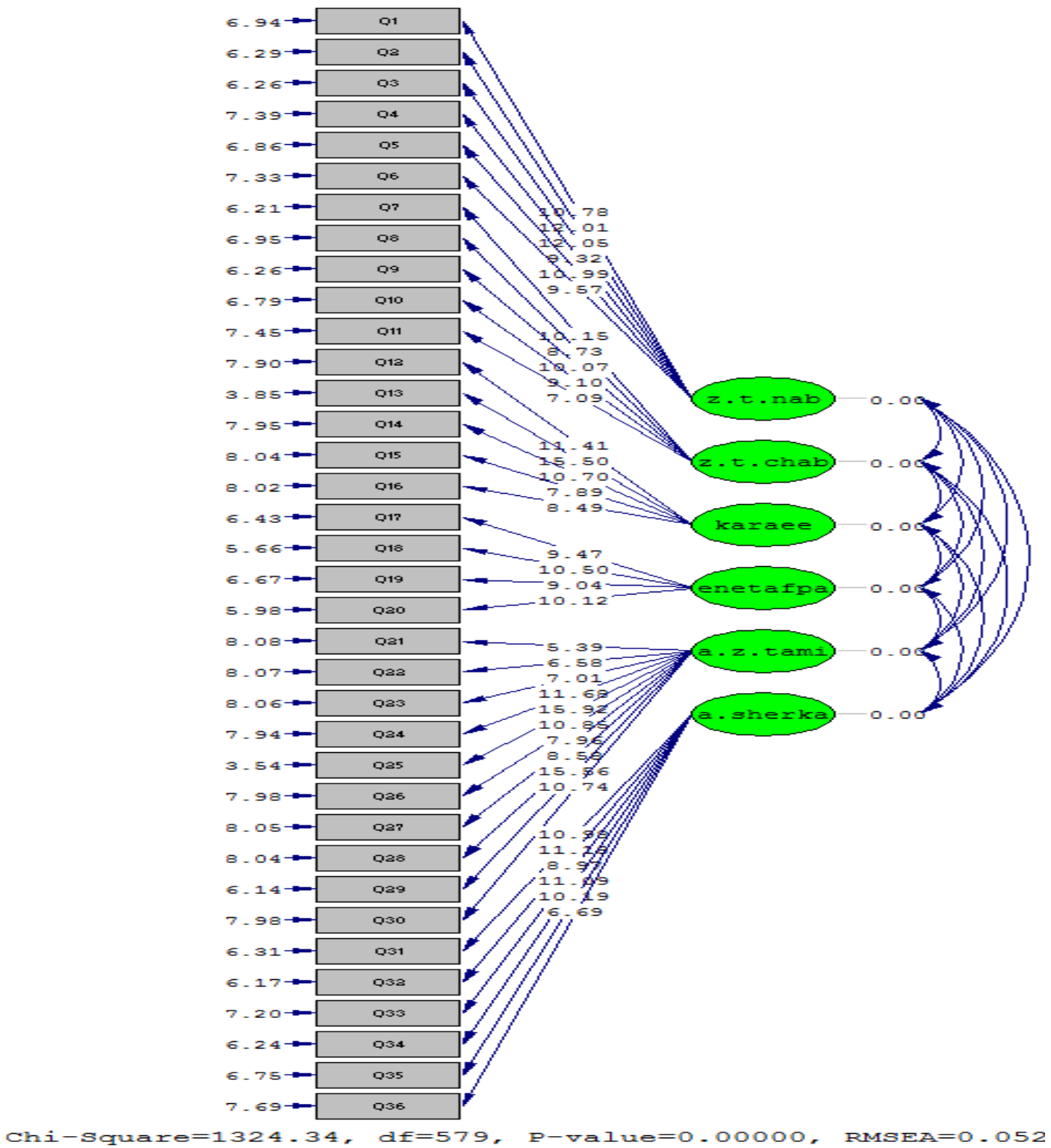

Fig. 3. Standardized estimates

TABLE IV. FIT INDEXES OF THE MODEL

\begin{tabular}{|c|c|c|c|c|}
\hline \multicolumn{2}{|c|}{ Fit index } & $\begin{array}{c}\text { Optimal } \\
\text { value }\end{array}$ & $\begin{array}{c}\text { Obtained } \\
\text { value }\end{array}$ & Result \\
\hline$\chi^{2} / d f$ & $\chi^{2} / d f$ & $\leq 3$ & 2.92 & Good fit \\
\hline $\begin{array}{c}\text { Root Mean Squared Error } \\
\text { of Approximation }\end{array}$ & RMSEA & $\leq 0.1$ & 0.052 & Good fit \\
\hline Normed Fit Index & NFI & $\geq 0.09$ & 0.93 & Good fit \\
\hline Non-Normed Fit Index & NNFI & $\geq 0.09$ & 0.95 & Good fit \\
\hline Comparative Fit Index & CFI & $\geq 0.09$ & 0.94 & Good fit \\
\hline Incremental Fit Index & IFI & $\geq 0.09$ & 0.95 & Good fit \\
\hline Goodness of Fit Index & GFI & $\geq 0.09$ & 0.92 & Good fit \\
\hline $\begin{array}{c}\text { Adjusted Goodness of Fit } \\
\text { Index }\end{array}$ & AGFI & $\geq 0.09$ & 0.9 & Good fit \\
\hline $\begin{array}{c}\text { Root Mean Square } \\
\text { Residual }\end{array}$ & RMR & $\leq 0.08$ & 0.04 & Good fit \\
\hline $\begin{array}{c}\text { Standardized Root Mean } \\
\text { Square Residual }\end{array}$ & SRMR & $\leq 0.08$ & 0.02 & Good fit \\
\hline
\end{tabular}

\section{Model with Estimates of Significance}

Only significance level of flexibility is lower than 1.96, while statistics of other paths are higher than 1.96. In other words, the relationships between all variables are significant except the relationships between flexibility of information systems and supply chain performance (Figure 4). PLS results for the standardized estimates show that $\beta$-value $=44.5 \%$ between lean supply chain and efficiency of information systems, $\beta$-value $=16.2 \%$ between lean supply chain and supply chain performance, $\beta$-value $=830.8 \%$ between agile supply chain and supply chain performance, $\beta$-value $=54.7 \%$ between agile supply chain and flexibility of information systems, $\beta$ value $=45.6 \%$ between efficiency of information systems and supply chain performance, $\beta$-value $=6.7 \%$ between flexibility of information systems and supply chain performance, $\beta$ - 
value $=67.1 \%$ between supply chain performance and firm performance (Figure 5).

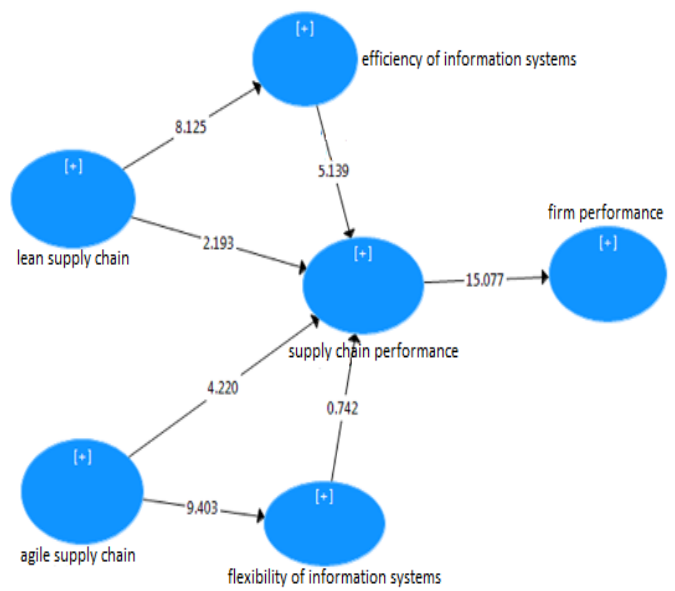

Fig. 4. Model with estimates of significance

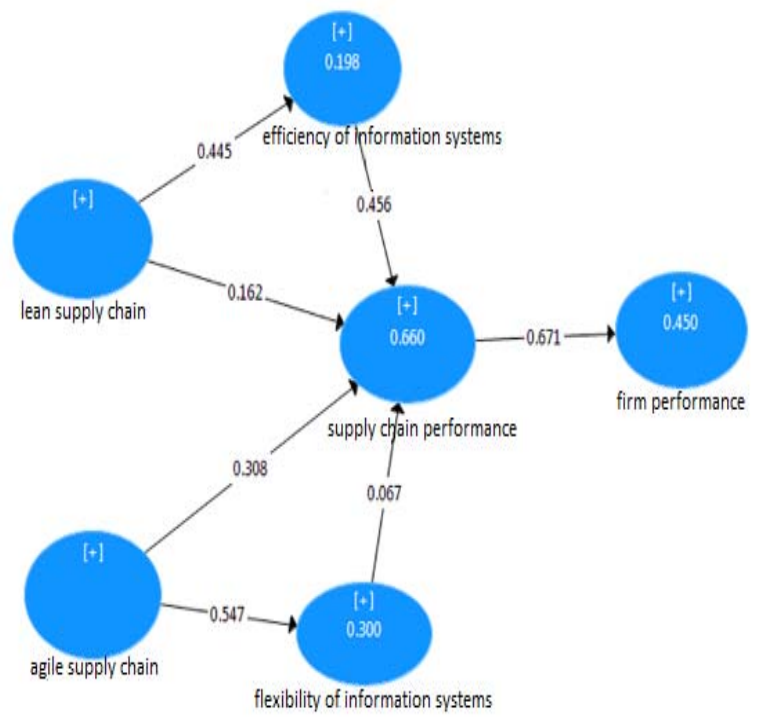

Fig. 5. Model with standardized estimates

\section{E. Model with Removed Moderators}

Figure 6 shows that significance level of all variables is higher than 1.96; thus, the relationships between all variables are significant. As shown in Figure 7, $\beta$-value $=31.3 \%$ between lean supply chain and supply chain performance, $\beta$ value $=49.2 \%$ between agile supply chain and supply chain performance and $\beta$-value $=67.1 \%$ between supply chain performance and firm performance. Results of hypothesis testing and comparison with previous studies are listed in Table V. Managerial implications are suggested in Table VI.

\section{CONCLUSION}

This study determined the moderating role of information systems (from perspectives of efficiency and flexibility) in the performance of IKAMCO. The results showed that efficiency of information system moderate the relationship between lean supply chain and supply chain performance and firm performance. Moreover, the results showed that flexibility of information systems does not moderate the relationship between lean supply chain and supply chain performance and firm performance. To improve performance of the organization, IKAMCO needs to increase flexibility and faster responsiveness to customers in order to use proper market management information systems such as CRM to acquire information feedbacks of market conditions and customers, as well as information systems of internal process management to establish or modify new product design process, increase quality of product, use intelligent tools in production, concentrate on team activities, increase delegation to employees, increase personnel skills, use new technologies, produce diverse products, use flexible line feeding system, and produce in different quantities.

TABLE V. RESULTS OF HYPOTHESIS TESTING

\begin{tabular}{|c|c|c|c|c|c|}
\hline & Hypothesis & $\begin{array}{c}\text { Test } \\
\text { statistic }\end{array}$ & $\begin{array}{c}\beta- \\
\text { value }\end{array}$ & Result & $\begin{array}{c}\text { Previous } \\
\text { result }\end{array}$ \\
\hline 1 & $\begin{array}{l}\text { Lean supply chain is } \\
\text { effective on supply chain } \\
\text { performance. }\end{array}$ & 2.193 & 0.162 & $\begin{array}{c}\mathrm{H}_{0} \\
\text { rejected } \\
\mathrm{H}_{1} \\
\text { accepted }\end{array}$ & $\begin{array}{c}\text { Consistent } \\
\text { with } \\
{[7,14]}\end{array}$ \\
\hline 2 & $\begin{array}{l}\text { Agile supply chain is } \\
\text { effective on supply chain } \\
\text { performance. }\end{array}$ & 4.220 & 0.308 & $\begin{array}{c}\mathrm{H}_{0} \\
\text { rejected } \\
\mathrm{H}_{1} \\
\text { accepted }\end{array}$ & $\begin{array}{c}\text { Consistent } \\
\text { with } \\
{[6,9,13} \\
15]\end{array}$ \\
\hline 3 & $\begin{array}{l}\text { Supply chain } \\
\text { performance is effective } \\
\text { on firm performance. }\end{array}$ & 15.077 & 0.671 & $\begin{array}{c}\mathrm{H}_{0} \\
\text { rejected } \\
\mathrm{H}_{1} \\
\text { accepted }\end{array}$ & $\begin{array}{l}\text { Consistent } \\
\text { with } \\
{[6,12,16]}\end{array}$ \\
\hline 4 & $\begin{array}{l}\text { Efficiency of information } \\
\text { systems moderates effect } \\
\text { of lean supply chain on } \\
\text { supply chain performance } \\
\text { and firm performance. }\end{array}$ & 5.139 & 0.456 & $\begin{array}{c}\mathrm{H}_{0} \\
\text { rejected } \\
\mathrm{H}_{1} \\
\text { accepted }\end{array}$ & $\begin{array}{l}\text { Consistent } \\
\quad \text { with } \\
{[8,10,17]}\end{array}$ \\
\hline 5 & $\begin{array}{l}\text { Flexibility of information } \\
\text { systems moderates effect } \\
\text { of agile supply chain on } \\
\text { supply chain performance } \\
\text { and firm performance. }\end{array}$ & 0.742 & 0.067 & $\begin{array}{c}\mathrm{H}_{0} \\
\text { accepted }\end{array}$ & $\begin{array}{c}\text { Consistent } \\
\text { with } \\
{[11,18]}\end{array}$ \\
\hline
\end{tabular}

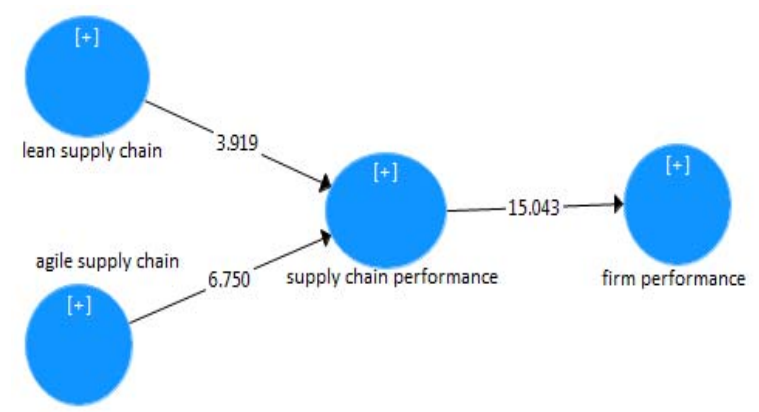

Fig. 6. Model with estimates of significance and removed moderators 


\section{TABLE VI. MANAGERIAL IMPLICATIONS}

H1: lean supply chain is effective on supply chain performance.

1. Improve ability of the organization to manage inventory in different stages of supply chain

2. Improve ability of supply chain to provide standard products by using modern strategies

3. Improve ability of the organization to manage non-standard orders

4. Increase ability of supply chain to reduce wastes

5. Increase ability of supply chain to provide and produce high quality products

6. Improve ability of supply chain to control quality of products H2: agile supply chain is effective on supply chain performance

7. Customize products by adding certain models required by customers

8. Respond effectively to variable needs of design

9. Increase ability of supply chain to change existing product or design new products

10. Increase ability of supply chain to manage inventory in order to meet customer needs H3: supply chain performance is effective on firm performance

11. Improve responsiveness to certain customer needs

12. Produce diverse products

13. Respond quickly to change or improve products

14. Introduce new products quickly to the market

15. Change production capacity quickly based on customer demands

16. Increase ability of supply chain to facilitate activities of the organization and business partners

17. Use outputs of integrated information systems in top management decisions, better interactions with suppliers and customers and monitoring of market changes

18. Facilitate delivery at short time periods

H4: efficiency of information systems moderates effect of lean supply chain on supply chain performance and firm performance

19. Improve efficiency of activities of suppliers and the organization

20. Manage inventory of suppliers and the organization optimally

21. Manage raw materials required by the organization and suppliers

22. Manage control of parts in production line of the organization and suppliers

23. Coordinate parts and information available in suppliers and production line

24. Introduce new products and services to the market

25. Monitor changes in the market

26. Increase ability of information systems to help the organization change design of products

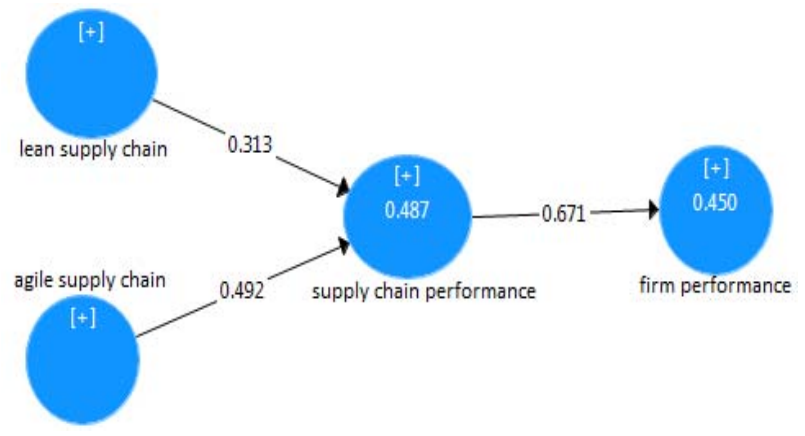

Fig. 7. Model with standardized estimates and removed moderators

\section{REFERENCES}

[1] N. F. Doherty, H. Fulford, "Do Information Security Policies Reduce the Incidence of Security Breaches: An Exploratory Analysis", Information Resources Management Journal, Vol. 18, No. 2, pp. 21-39, 2005

[2] M. Gerber, R. von Solms, "Management of risk in the information age", Computers \& Security, Vol. 24, No. 1, pp. 16-30, 2001

[3] M. E. Porter, V. E. Millar, "How information gives you competitive advantage", Harvard Business Review, July, 1985

[4] A. Agrawal, R. Shankar, M. K. Tiwari, "Modeling the metrics of lean, agile and leagile supply chai An ANP-based approach", European Journal of Operational Research, Vol. 173, No. 1, pp. 211-225, 2006

[5] A. Jafarnejad, B. Shahaei, Organizational agility and agile production. 1st ed. Tehran: Nashr Mehrban, 2007

[6] S. Qrunfleh, M. Tarafdar, "Supply chain information systems strategy: Impacts on supply chain performance and firm performance", International Journal of Production Economics, Vol. 147, No. 1, pp. 340-350, 2014

[7] M. R. Dalavi-Esfahani, H. Ghorbani, M. Bagheri-Ghalesalimi, "Effect of aligned marketing strategies on supply chain and performance", Marketing Management, Vol. 9, No. 23, pp. 95-109, 2014

[8] S. Varedi, M. Rostami-Norouzabad, S. Rahmani-Norouzabad, Z. Samadi, "Effect of IT on supply chain capabilities and firm performance; a case study: SAIPA", Industrial Management, Vol. 8, No. 24, pp. 159-169, 2013

[9] F. Kianfar, "Role of information systems of strategic management in strategic decisions", Tomorrow Management, Vol. 7, No. 19, pp. 65-75, 2008

[10] A. Amid, A. Rezaeian, M. Bagheri, "Analysis of effect of strategic planning in information systems for improving supply chain management performance", Business Management Vision, Vol. 7, No. 25 , pp. 5-32, 2007

[11] P. Marinagi, P. Trivellas, C. Reklitis, "Information quality and supply chain performance: the mediating role of information sharing", Procedia - Social and Behavioral Sciences, Vol. 15, No. 12, pp. 473-479, 2015

[12] H. Lee, M. Sun Kim, K. Kim, "Interorganizational information systems visibility and supply chain performance", International Journal of Information Management, Vol. 34, No. 2, pp. 285-295, 2014

[13] A. J. Gilbert Silvius, J. Stoop, "The Relationship between Strategic Information Systems Planning Situational Factors", Journal of International Technology and Information Management, Vol. 22, No. 1, Art. No. 1, 2013

[14] R. Rajaguru, M. Jekanyika Matanda, "Effects of inter-organizational compatibility on supply chain capabilities: Exploring the mediating role of inter-organizational information systems (IOIS) integration", Industrial Marketing Management, Vol. 42, No. 4, pp. 620-632, 2013

[15] H. Daoud, M. Triki, "Accounting Information Systems in an ERP Environment and Tunisian Firm Performance", The International Journal of Digital Accounting Research, Vol. 13, No. 1, pp. 1 - 35, 2013

[16] U. Sadiq, A. Fareed Khan, K. Ikhlaq, G. Bahaudin, N. Mujtaba, "The Impact of Information Systems on the Performance of Human Resources Department", Journal of Business Studies Quarterly, Vol. 3, No. 4, pp. 77-91, 2012

[17] S. Petter, W. DeLone, E. Mc Lean, "Measuring information systems success: models, dimensions, measures, and interrelationships", European Journal of Information Systems, Vol. 17, No. 4, pp. 236-263, 2008

[18] R. Haji-Jabari, S. Yazdani, E. Dadashi-Khas, "Effect of accounting information systems on organizational performance", Productivity Management, Vol. 6, No. 23, pp. 125-148, 2012 